\title{
Article
}

\section{The Effect of Heat Treatment on the Structure of Zeolite A}

\author{
Magdalena Katarzyna Król *(D) and Piotr Jeleń (D)
}

Faculty of Materials Science and Ceramic, AGH University of Science and Technology, 30 Mickiewicza Av., 30-059 Krakow, Poland; pjelen@agh.edu.pl

* Correspondence: mkrol@agh.edu.pl

\section{check for}

updates

Citation: Król, M.K.; Jeleń, P. The Effect of Heat Treatment on the Structure of Zeolite A. Materials 2021, 14, 4642. https://doi.org/10.3390/ ma14164642

Academic Editor: Bruno de Gennaro

Received: 19 July 2021

Accepted: 12 August 2021

Published: 18 August 2021

Publisher's Note: MDPI stays neutral with regard to jurisdictional claims in published maps and institutional affiliations.

Copyright: (c) 2021 by the authors. Licensee MDPI, Basel, Switzerland. This article is an open access article distributed under the terms and conditions of the Creative Commons Attribution (CC BY) license (https:// creativecommons.org/licenses/by/ $4.0 /)$.

\begin{abstract}
Knowledge about the thermal properties of zeolites is extremely important due to their potential application in the chemical industry. In this work, the thermal stability and the dehydration process of zeolite A were investigated by in situ high temperature Fourier transform infrared spectroscopy. The progress of thermal decomposition that zeolite A underwent during the controlled temperature increase in the range of $25-600{ }^{\circ} \mathrm{C}$ was determined by the DRIFT spectroscopic method. Infrared spectra are presented and discussed for this compound on the basis of the crystal structure. Based on the courses of the obtained DRIFT spectra, it was found that, during heating, water was gradually removed from the structure of the material, followed by dehydration and formation of hydrogen bonds. It was established that the process of thermal degradation began as early as $550{ }^{\circ} \mathrm{C}$. The analysis of the obtained results of structural tests can be repeated on other materials from the zeolite group and complements the research work on the thermal analysis of these materials.
\end{abstract}

Keywords: zeolite A; thermal stability; dehydration; DRIFT spectroscopy; in situ measurement

\section{Introduction}

Zeolites are crystalline, hydrated aluminosilicates built of aluminum and silica tetrahedrons (so-called primary building units-PBUs) connected at the corners to form a spatial network [1]. The lattice of these aluminosilicates is composed of one or more structural units which are differently connected, which determines the different zeolite topologies. The zeolite structure is formed by a system of chambers and channels [2]. The chambers are usually in the shape of polyhedra with empty spaces inside. Their size depends largely on the structural arrangement of the PBUs. The size and the shape of the channels are important in selecting cations and molecules that can enter the interior of the crystal.

Due to their properties, zeolites are widely used in various branches of the chemical industry [3]. They can be found in areas such as microelectronics, optics, medicine, and agriculture. The physio-chemical properties that determine such a wide application range include high adsorption capacity, molecular sieve capacity, high selectivity, ion exchange capacity, as well as resistance to acids and elevated temperatures. The high inner surface area of zeolites has many types of active sites of different strength depending on the type of structure. Materials with such a large possibilities of surface and physio-chemical properties modifications are used as adsorbents, ion exchangers, and catalysts.

Among the many known structures, zeolite A deserves special attention. It is one of the most studied and used synthetic zeolites, the discovery of which became a breakthrough for the petroleum processing industry. At the same time, it also became the most commonly used in many areas of everyday life (detergents, insulating glasses, etc.). It is a material obtained by synthesis from readily available raw materials at a not too high temperature, and the process itself is relatively simple [4].

Zeolite A was chemically and structurally (both experimental and theoretical) investigated in several early studies [5-8]. Its ideal chemical formula is $\mathrm{Na}_{96}\left[\mathrm{Al}_{96} \mathrm{Si}_{96} \mathrm{O}_{384}\right] \cdot 216 \mathrm{H}_{2} \mathrm{O}$. The zeolite A structure is presented in Figure 1. Its space group was determined to be $\overline{\mathrm{P}} 3$, and the positions of all non-hydrogen atoms and, thus, the geometry, were provided; 
positions of the H-bonds were only inferred. Small changes in cation positions and in the zeolite framework were observed upon dehydration [9].

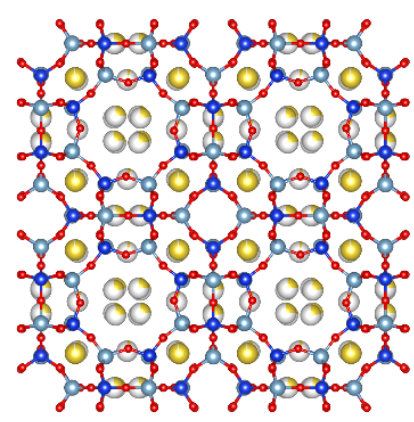

(a)

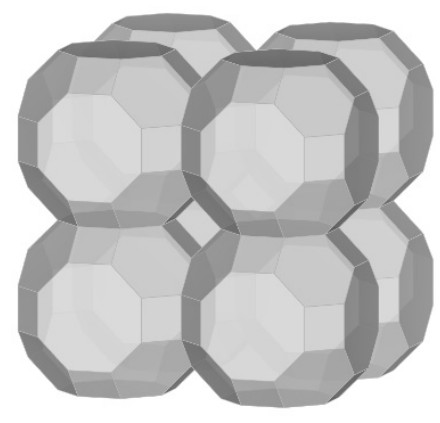

(b)

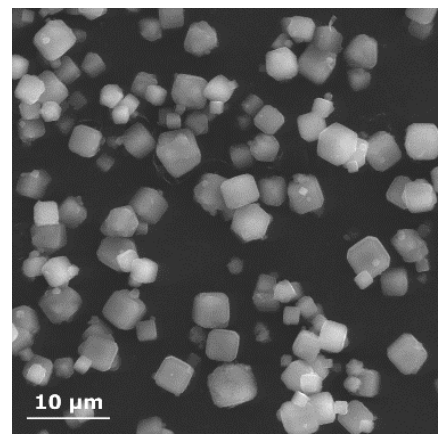

(c)

Figure 1. Zeolite Na-A crystal lattice: (a) model structure of zeolite Na-A; (b) simplified representation of zeolite A crystal structure highlighting the atomic cavities occupied by cations (prepared with the use of VESTA software [10] based on the .cif file available on the [2]); (c) SEM image of zeolite A.

Different techniques were applied to analysis of thermal behavior of zeolites. Among other common methods of thermal analysis such as differential thermal and thermogravimetric analysis (DTA and TG), heating in a furnace attached to the diffractometer can be considered as useful. IR spectroscopy is one of the most common methods for investigation of zeolite structure. Using in situ DRIFT technique, the formation of hydroxyl groups, the dehydration/rehydration processes, and the interaction of $\mathrm{OH}$ groups with various encaged and adsorbed species can be observed [11]. For example, based on the areas under the DRIFT spectra of zeolite $Y$, the desorption profiles was calculated [12]. It was found that their shape was principally identical to the desorption curves obtained by conventional temperature-programmed desorption techniques.

Both adsorptive and catalytic properties of zeolites depend not only on the kind of extra-framework cations [13] but also are strongly determined by their water content. Metal impregnation was mainly used to improve the zeolites catalytic properties [14,15]. The aim of this study was to summarize and obtain more detailed structural information on the zeolite A by studying its sodium and ion-exchanged forms. In this study, we examined thermal behavior of zeolite A by in situ high temperature spectroscopic data and discussed the results on the basis of the structural features.

\section{Materials and Methods}

Pure synthetic zeolite A as its sodium form was used as the starting material. Zeolite $\mathrm{Na}-\mathrm{A}$ was synthesized under hydrothermal conditions using the procedure described in [16]. To obtain other cationic forms, initial zeolite Na-A was treated by water solution of $\mathrm{Ca}-, \mathrm{Cu}-, \mathrm{Ni}-$, or $\mathrm{Zn}$-nitrates. The concentration of the solutions was $0.01 \mathrm{~mol} / \mathrm{dm}^{3}$. Ion exchange was carried out at $60^{\circ} \mathrm{C}$ for $24 \mathrm{~h}$. After the ion exchange process, the samples were centrifuged and washed several times with distilled water. Phase composition of resulting samples was confirmed using X-ray diffraction. The results were obtained using Empyrean diffractometer (PANanalitycal, Malvern, Great Britain) using Bragg-Brentano geometry and CuKa radiation (measuring time was $4 \mathrm{~h}$, and step over was $0.05^{\circ}$ ).

The DRIFT measurements were performed on a Vertex $70 \mathrm{v}$ spectrometer (Bruker, Billerica, MA, USA) equipped with a DTGS detector using a Praying Mantis DRIFT attachment (Harrick Scientific Products, Pleasantville, NY, USA). The samples were measured at temperatures up to $600{ }^{\circ} \mathrm{C}$ under ambient pressure in Kubelka-Munk scale [17]. Heating rate was set to $5{ }^{\circ} \mathrm{C}$ per minute. In total, 64 scans with a $10 \mathrm{kHz}$ scanner velocity were acquired each minute. Spectral deconvolution was carried out using SpectraCalc software (Galactic Industries Corp., Main St Salem, NH, USA). A mixture of Gaussian-Lorentzian with a starting ration of 0.5 was created. As a result, a set of fitted bands with an RMS error below 1 was obtained. 
For comparative purposes, the water contents were obtained by heating $10 \mathrm{mg}$ samples in platinum crucibles at $5^{\circ} \mathrm{C} / \mathrm{min}$ in air using a thermal analyzer Netzsch STA 449 F3 Jupiter (Netzsch, Selb, Deutschland).

\section{Results and Discussion}

The average particle size of zeolite A was $1 \mu \mathrm{m}$ (as observed with SEM; Figure 1c), and it did not contain any other crystalline phases as impurity (checked by XRD; Figure S1). Its dehydration behavior was investigated based on thermal analysis (Figure 2), and selected temperature points were determined for additional structural investigations.

Thermal stability is traditionally determined by thermal analysis. TG-DSC curves of zeolite A are presented in Figure 2. Thermogravimetric analysis showed endothermic weight loss due to dehydration. Mass loss for the quasi-pure zeolite A agreed well with other literature data [1]. At $400{ }^{\circ} \mathrm{C}$, the major part of the dehydration was completed. The sample also contained a small amount of surface and zeolite water, noticeable at a mass loss below $180{ }^{\circ} \mathrm{C}$. The second step with lower slope was observed between 200 and $360{ }^{\circ} \mathrm{C}$ (mass loss of $2.9 \mathrm{wt}$.\%). Two step water loss was attributed to subsequent $\alpha$ - and $\beta$-cages dehydration [6]. Complete water loss was about $20.5 \mathrm{wt} . \%$, which was slightly less than $22.2 \mathrm{wt}$ \% calculated for $\mathrm{Na}_{96}\left[\mathrm{Al}_{96} \mathrm{Si}_{96} \mathrm{O}_{384}\right] \cdot 216 \mathrm{H}_{2} \mathrm{O}$ empirical formula) [6]. The obtained value agreed well with the previous results [18,19]. It is also well known [20] that most zeolites are not fully hydrated at room conditions but continue to hydrate as relative humidity is increased to $100 \%$.

Decarbonation components of the sample could occur from about $300{ }^{\circ} \mathrm{C}$, hence, the presence provided negligible effects on the DSC curve. The zeolite commonly showed an exothermic peak at about $900{ }^{\circ} \mathrm{C}$ due to the formation of amorphous aluminosilicate by destruction of the zeolite structure and its subsequent recrystallization into a new phase [21,22]. Dehydrated zeolite A was stable up to $800^{\circ} \mathrm{C}$, when it recrystallized into a $\beta$-cristobalite-type structure [1].

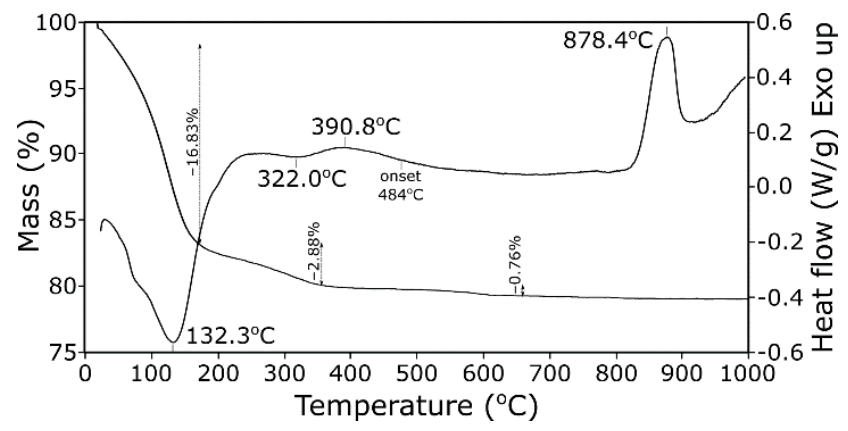

Figure 2. TG-DSC curves of zeolite Na-A.

The FT-IR spectrum of zeolite A in the $4000-400 \mathrm{~cm}^{-1}$ range is displayed in Figure 3 (spectra of all cationic forms are presented as Figure S2). Based on the interpretation of both the theoretical D4R units spectrum [23] as well as the spectrum of the simplified periodic model of zeolite A [24], vibrations of the following bands were assigned:

- $\quad 1005 \mathrm{~cm}^{-1}$ —asymmetric stretching vibrations of bridge bonds $-v_{\mathrm{as}} \mathrm{Si}-\mathrm{O}(\mathrm{Al})$

- $\quad 726 \mathrm{~cm}^{-1}$ — symmetric stretching vibrations of bridge bonds- $-v_{\mathrm{s}} \mathrm{Si}-\mathrm{O}-\mathrm{Si}$

- $666 \mathrm{~cm}^{-1}$ - symmetric stretching vibrations of bridge bonds $-v_{\mathrm{s}} \mathrm{Si}-\mathrm{O}-\mathrm{Al}$

- $554 \mathrm{~cm}^{-1}$ - (complex band) symmetric stretching vibrations of bridge bonds $-v_{\mathrm{s}}$ $\mathrm{Si}-\mathrm{O}-\mathrm{Si}$ and bending vibrations- $\delta \mathrm{O}-\mathrm{Si}-\mathrm{O}$

- $465 \mathrm{~cm}^{-1}$ — bending vibrations - $\delta \mathrm{O}-\mathrm{Si}-\mathrm{O}$, occurring in "antiphase"

- $\quad 379 \mathrm{~cm}^{-1}$-bending vibrations- $\delta \mathrm{O}-\mathrm{Si}-\mathrm{O}$ and $\delta \mathrm{O}-\mathrm{Al}-\mathrm{O}$ 

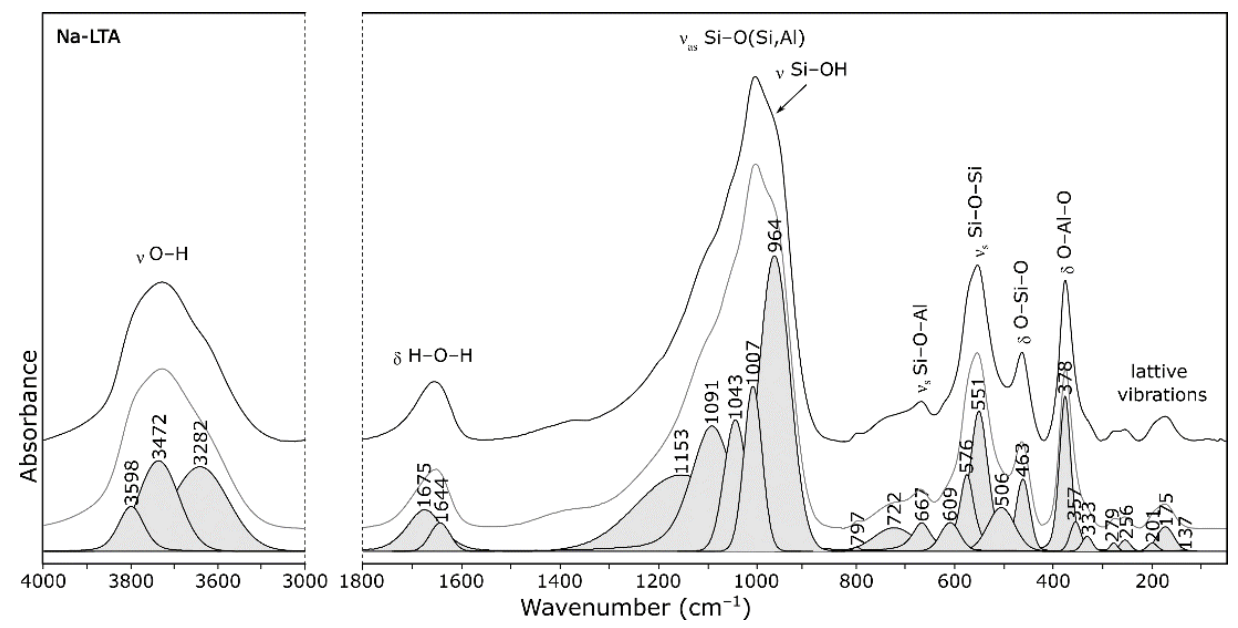

Figure 3. FT-IR spectrum of zeolite Na-A.

Additionally, in the $\mathrm{OH}$ stretching region $\left(3000-4000 \mathrm{~cm}^{-1}\right)$, very intense peaks in a superposition of several component bands with maximum at ca. $3450 \mathrm{~cm}^{-1}$ were observed. Two intense bands were also observed in the $\mathrm{H}_{2} \mathrm{O}$ bending region at ca. $1650 \mathrm{~cm}^{-1}$. A very weak and broad band was finally observed around $3245 \mathrm{~cm}^{-1}$ that could be finally assigned to the first overtone of the $\mathrm{H}_{2} \mathrm{O}$ bending mode.

The DRIFT spectra were recorded as a function of temperature for the sodium form of zeolite A and a zeolite sample exchanged with different metals. Resulting spectra are shown in Supplementary Materials in full wavenumber range as Figures S3-S7. Figures 4-6 show the spectra in a smaller wavenumber range.

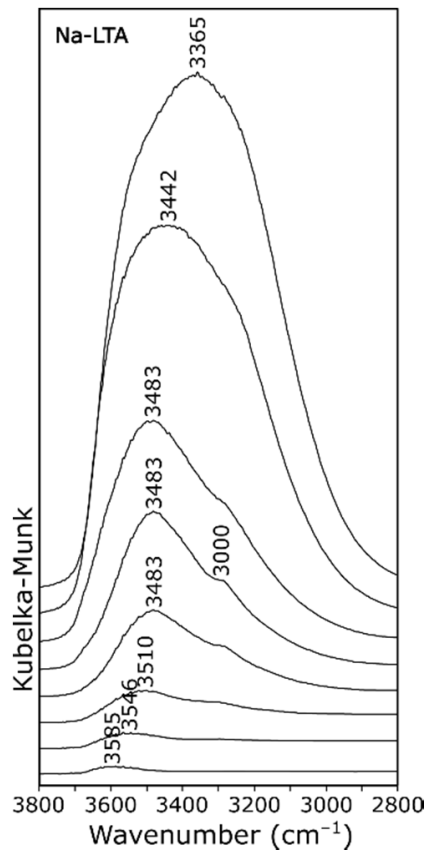

(a)

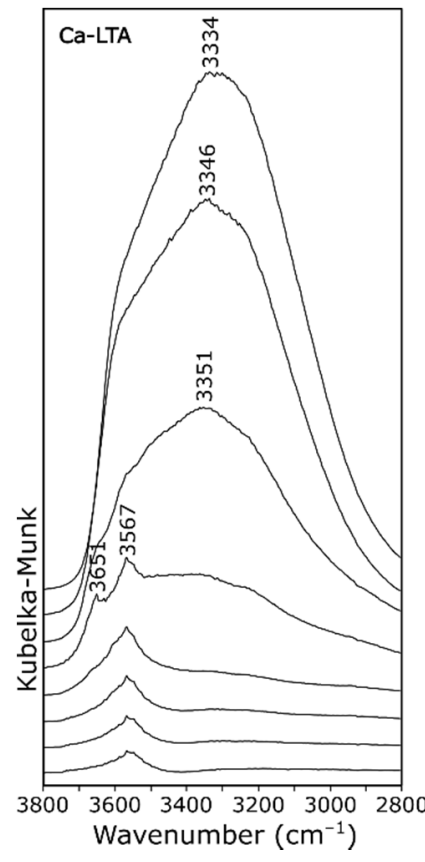

(b)

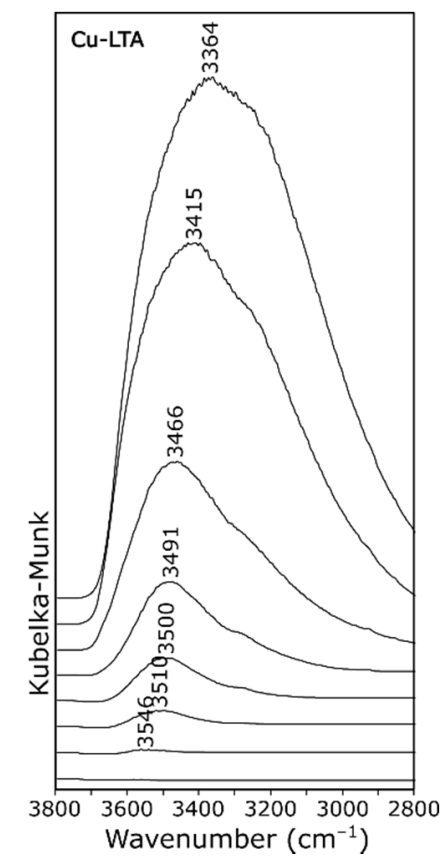

(c)

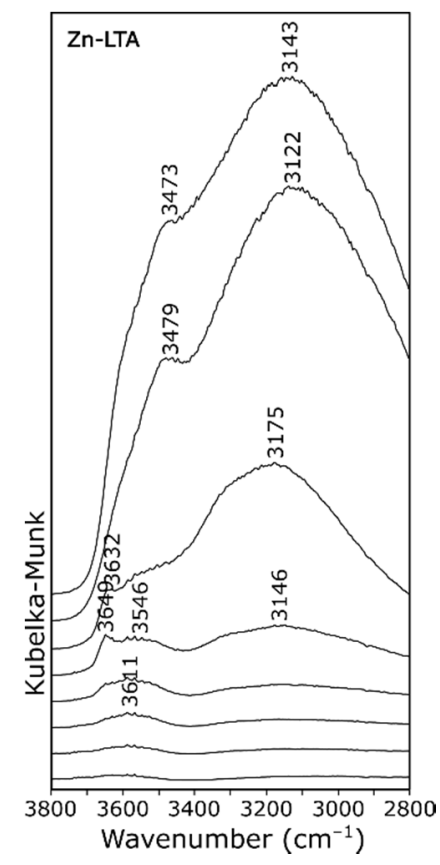

(d)

Figure 4. DRIFT spectra of zeolite A recorded at $50{ }^{\circ} \mathrm{C}$ intervals (from 50 to $400{ }^{\circ} \mathrm{C}$, respectively, from top to bottom): (a) $\mathrm{Na}-\mathrm{A}$; (b) Ca-A; (c) Cu-A; and (d) Zn-A.

Changes in the spectral envelope to about $400{ }^{\circ} \mathrm{C}$ were mainly related to water loss (Figure 4). The zeolite dehydration took place up to the temperature of about $180^{\circ} \mathrm{C}$, hence, the intensity of the band with a large FWHM (full width at half maximum) disappeared at about $3350 \mathrm{~cm}^{-1}$ for all measurement series. At the same time, the band at about $1600 \mathrm{~cm}^{-1}$, 
related to the $\mathrm{H}-\mathrm{O}-\mathrm{H}$ bending vibrations, also disappeared (Supplementary Materials). There is evidence in the literature for the correlation between the integral intensity of the mentioned bands and the amount of adsorbed water, the so-called bulk water [12,25]. This reduction is different for zeolites exchanged with different metals, because metals differ in their ability to surround themselves with water molecules.

The other bands observed in this range were associated with stretching vibrations of $\mathrm{OH}$ groups of structural water molecules and $\mathrm{OH}$ functional groups. The deconvolution of the exemplary spectra obtained at $200{ }^{\circ} \mathrm{C}$ (Figure 5) revealed that, in this range, at least three bands could be distinguished. Two very intense and well resolved peaks at 3468 and $3282 \mathrm{~cm}^{-1}$, respectively, were observed in the case of spectrum of zeolite Na-A (Figure 5a). At a closer inspection, an additional two shoulders at 3552 and $3667 \mathrm{~cm}^{-1}$ were evident, especially at higher temperatures. These wavenumbers were similar to those described in related literature $[26,27]$. Following the bands assignment proposed in the work [26], the bands could be assigned successively: $3282 \mathrm{~cm}^{-1}$ to molecules arranged in a tetrahedral "ice-like" hydrogen bonded network; $3468 \mathrm{~cm}^{-1}$ to water molecules involved in two H-bonds; and $3552 \mathrm{~cm}^{-1}$ to molecules of monomeric structures or assembled to form dimers by linear H-bonds. The shifting of the above-mentioned bands towards higher wavenumbers with increasing temperature (Figure 4a) resulted from partial dehydration and, thus, weakening of interactions between individual molecules due to the loss of some hydrogen bonds. The band at about $3580 \mathrm{~cm}^{-1}$ disappeared completely at the temperature of $400{ }^{\circ} \mathrm{C}$, which proved complete dehydration and agreed with the results obtained for the TG-DSC analysis (Figure 2).

The last band (at $3667 \mathrm{~cm}^{-1}$ ) could be assigned to the $\mathrm{Si}-\mathrm{OH}-\mathrm{Al}$ group (bridging hydroxyl groups). This band disappeared above $200{ }^{\circ} \mathrm{C}$. A similar band was attributed to vibrations of corresponding groups in the structure of thermal activated zeolite $\mathrm{X}$ [28] or mordenite [29]. By contrast, as the temperature increased, the shoulder at $3650 \mathrm{~cm}^{-1}$ was more evident in the case of Ca form (Figure $4 \mathrm{~b}$ ). Similar results were described in the work [30]. Na-A zeolite showed the presence of small amounts of molecular water, while Ca-A zeolite showed the presence of non-acidic $\mathrm{CaOH}^{+}$groups and of symmetrical carbonate ions as well as small traces of acidic $\mathrm{OH}$ functionalists. The band at about $3569 \mathrm{~cm}^{-1}$ in the spectrum of zeolite Ca-A presented in Figure $4 \mathrm{~b}$ was caused by $\mathrm{Ca}(\mathrm{OH})^{+}$ absorbance. This phenomena can be explained by the Hirschler-Plank dissociative water adsorption model [19]. Interestingly, this band was not observed in any other series of measurements.

It was expected that, with the appearance of stretching vibrations originating from $\mathrm{OH}$ groups in the spectrum of the zeolite, the corresponding bending vibrations would also appear. Positions of this band were recognized in the related literature and ranged from 1060 to $1020 \mathrm{~cm}^{-1}$ [31,32]. The authors of work [12], on the other hand, noticed that the strong overlapping of the bands due to $\mathrm{OH}$ bending vibrations strongly overlapped with the $\mathrm{Si}-\mathrm{O}$ stretching vibrations and could not be detected with the use of IR investigations. In our work, there were evident bands at about 1055 and $1067 \mathrm{~cm}^{-1}$ (Figure 6), which agreed well with the results presented in the work [32].

The copper and the nickel forms of zeolite were selected for this research due to their potential use in catalysis [33]. The envelopes of both spectra (Figure 4c) were similar to the sodium form of zeolite $\mathrm{A}$, possibly because both $\mathrm{Cu}^{2+}$ and $\mathrm{Ni}^{2+}$ ions occupied the same site as $\mathrm{Na}^{+}$(the center of the six-membered ring in $\alpha$-cage) [34]. The lack of acid centers could be explained, on the one hand, by the high proportion of aluminum in the zeolite A structure and, on the other hand, the tendency of the analyzed ions to form dimers, e.g., $\mathrm{Cu}-\mathrm{Cu}$ and $\mathrm{Ni}-\mathrm{Ni}$ bonds. This property was theoretically confirmed in our previous work [24].

The $\mathrm{Zn}$ form of zeolite was characterized by a modified surface charge due to the generation of new Lewis acid sites and variable redox properties of zeolites [35], which influenced, among other things, the selective adsorption of cationic dyes [36]. The zinc form of zeolite A had a completely different course of the IR spectrum in the discussed 
range (Figure $4 \mathrm{~d}$ ). Some of the zinc ions were probably adsorbed at surface-bridging hydroxyls $\equiv \mathrm{Si}-\mathrm{OH}-\mathrm{Al} \equiv$ or at surface hydroxyls $\equiv \mathrm{Si}-\mathrm{OH}, \equiv \mathrm{Al}-\mathrm{OH}$ with the formation of $\mathrm{Me}(\mathrm{OH})(\mathrm{OZe})$ complex [37]. Hydroxycomplexes $\mathrm{Zn}(\mathrm{OH})_{\mathrm{p}} \mathrm{Ze}_{2}{ }^{-\mathrm{p}} \mathrm{Zn}$, similarly to zinc hydroxides, were more insoluble than the hydroxycomplexes of the remaining investigated metals, which resulted in a large amount of structured water. This hypothesis was confirmed by the appearance of a band at ca. $3649 \mathrm{~cm}^{-1}$, analogous to that visible in the spectrum of the Ca-form.

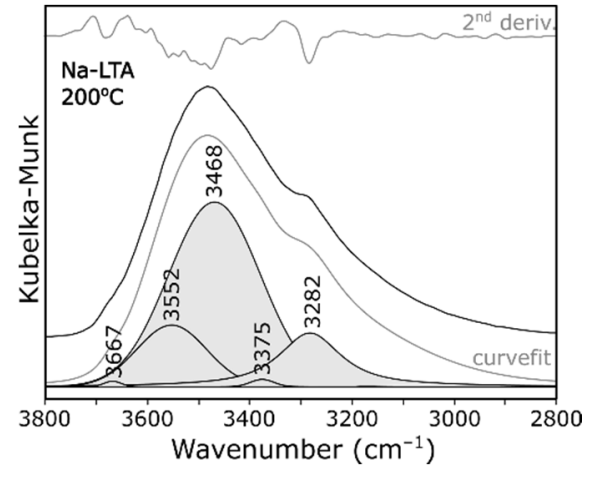

(a)

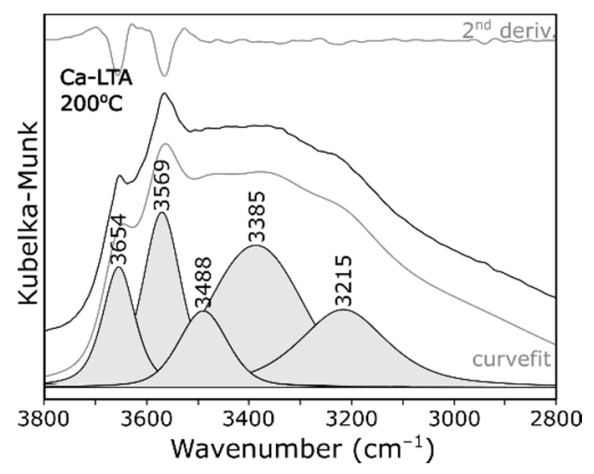

(b)

Figure 5. Decomposition of the spectra recorded at $200^{\circ} \mathrm{C}$ : (a) Na-LTA; and (b) Ca-LTA.

Figures 6 and 7 show the DRIFT spectra of zeolite $\mathrm{A}$ in the range of $\mathrm{Si}-\mathrm{O}-\mathrm{Al}$ vibration modes. In the initial zeolite (zeolite Na-A; Figure 6a), absorption bands were observed at $1010 \mathrm{~cm}^{-1}$ (with a shoulder at $1150 \mathrm{~cm}^{-1}$ ), 950, 669, 556, and $470 \mathrm{~cm}^{-1}$. The band at ca. $950 \mathrm{~cm}^{-1}$ was due to stretching $\mathrm{Si}-\mathrm{OH}$, and its change in intensity corresponded well with the observations for the $\mathrm{SiO}-\mathrm{H}$ band (at ca. $3600 \mathrm{~cm}^{-1}$ ); it gradually disappeared as the temperature rose. At higher values of the wavenumber, there was a broad band with a maximum at $1010 \mathrm{~cm}^{-1}$ and a shoulder at $1150 \mathrm{~cm}^{-1}$. Both 1150 and $1010 \mathrm{~cm}^{-1}$ bands were attributed to asymmetric stretching vibrations of $\mathrm{Si}-\mathrm{O}$. The shoulder was attributed to the location of silicon atoms on different oxygen atoms in the framework. The ( $\mathrm{Si}-\mathrm{O}-(\mathrm{Al})$ band shifted to the lower wavenumber as the temperature increased. The probable reason is that the cation lacking a hydration shell more strongly attracted silicon, which led to an elongation of the $\mathrm{Si}-\mathrm{O}$ bond (lowering its force constant). The same interpretation could be transferred to other forms of zeolite, e.g., $\mathrm{Cu}-\mathrm{A}$ in Figure $6 \mathrm{~b}$.

The spectra of zeolite Ca-A in Figure 7a, especially Zn-A in Figure 7b, showed a significantly different course compared to the other forms. The differences, however, came down to the shifting of some bands in relation to each other, which gave the visual effect of splitting the bands. Theoretical studies on the structure of the anhydrous form of zeolite A [24] showed that such an effect is a direct consequence of the position of individual extra-framework cations (in relation to the six-membered ring (B site according to [7,38])). The cations that bound more strongly to the skeleton (e.g., d-block cations such as $\mathrm{Zn}^{2+}$ ) distorted it more, resulting in the formation of more than one type of $\mathrm{Si}-\mathrm{O}$ bond.

According to literature [23,39], the band at about $555 \mathrm{~cm}^{-1}$ corresponded to symmetric stretching vibrations of double four-membered rings in the LTA structure. Its complex envelope indicated that it was a superposition of several component bands. Calculated spectra indicated the typical ring vibration ( $\mathrm{PO}$ - pore opening vibration) gave a band at lower wavenumbers. The presence of this band in discussed spectra indicated that this unit (double four-membered ring) was maintained in the entire analyzed temperature range. 


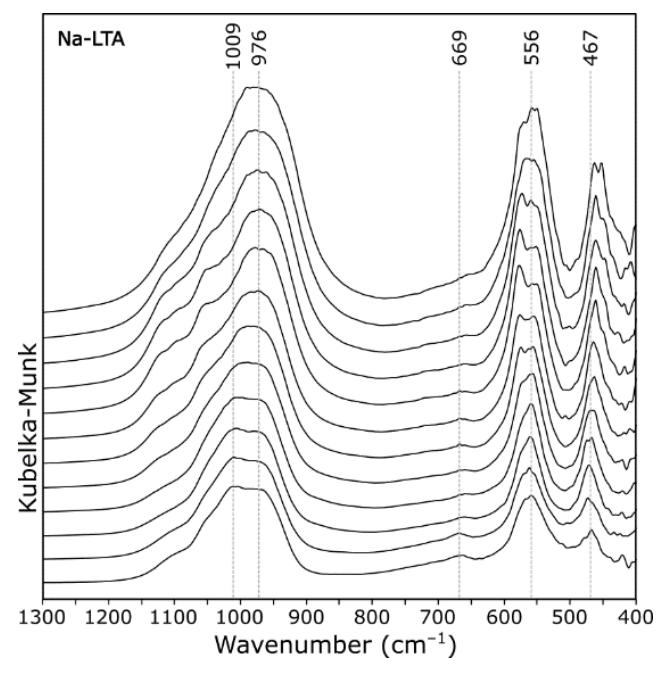

(a)

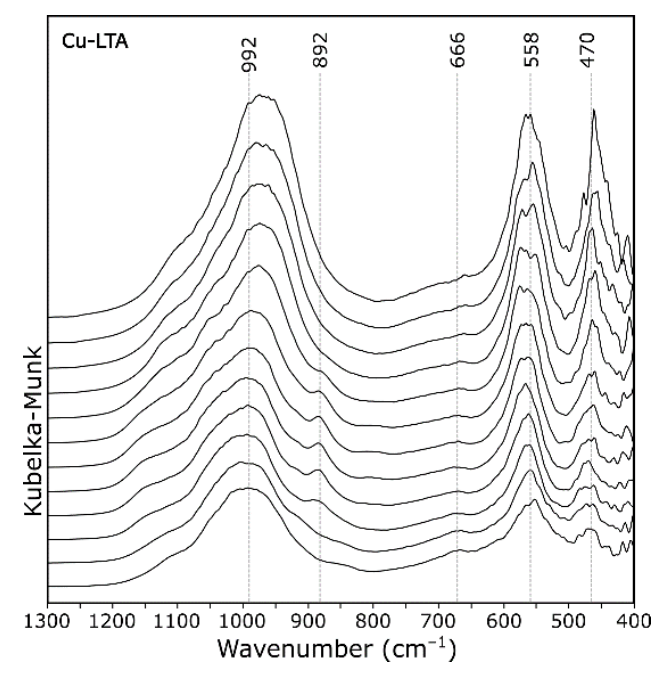

(b)

Figure 6. DRIFT spectra of zeolite A recorded at $50{ }^{\circ} \mathrm{C}$ intervals (from 50 to $600{ }^{\circ} \mathrm{C}$ ): (a) Na-A; and (b) Cu-A.

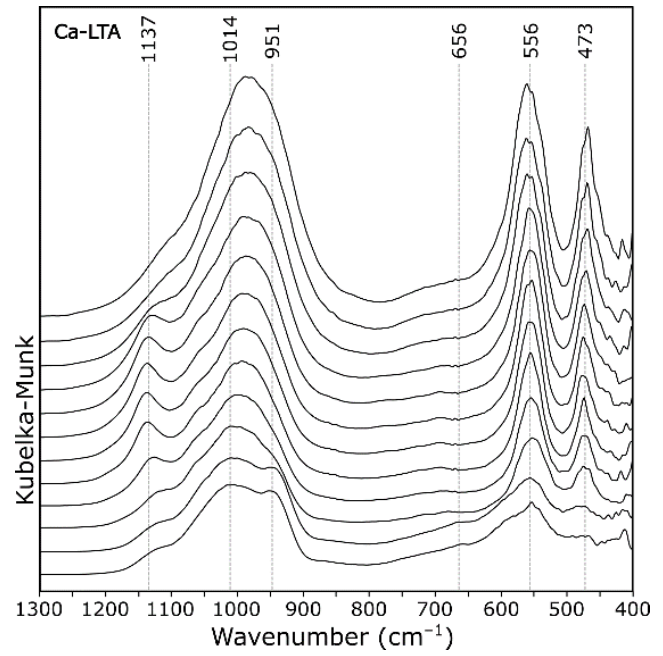

(a)

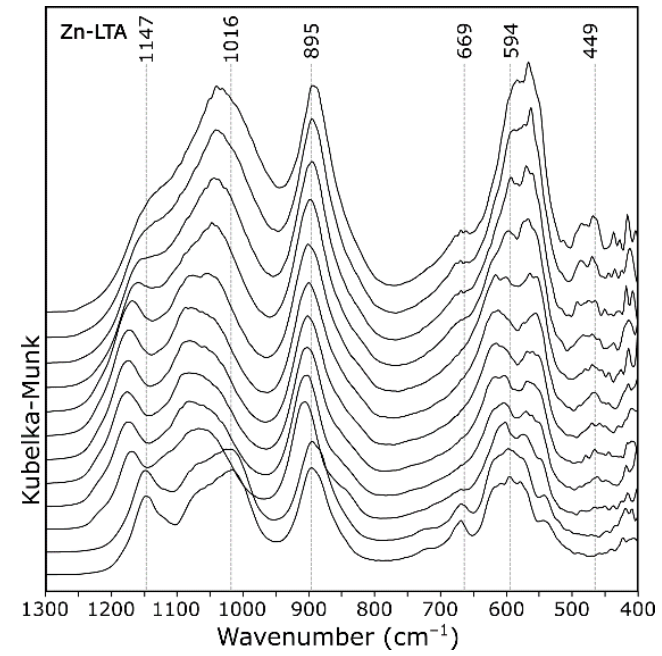

(b)

Figure 7. DRIFT spectra of zeolite A recorded at $50{ }^{\circ} \mathrm{C}$ intervals (from 50 to $600{ }^{\circ} \mathrm{C}$ ): (a) Ca-A; and (b) Zn-A.

It is well known that zeolite A is not as thermally stable as other zeolites. For example, zeolite Ca-A loses its sorptive ability towards organic vapors if the temperature exceeds $350{ }^{\circ} \mathrm{C}$ [40]. At $500{ }^{\circ} \mathrm{C}$, first indications of partial collapse of a zeolite A structure (regardless of the cationic form) were evident in DRIFT spectra (Figure 6). Discussed zeolite structural collapse was followed by formation of an amorphous matter, resulting in an increase in the bands FWHM. It agreed well with the results of X-ray powder diffraction experiments [41] that such a prepared amorphous $\mathrm{NaAlSiO}_{4}$ substance was stable between $850{ }^{\circ} \mathrm{C}$ and $900{ }^{\circ} \mathrm{C}$. As part of this study, further heating of the system was not possible due to the apparatus limitations resulting from the specificity of the method.

\section{Conclusions}

The DRIFT technique is used to test powders and rough surfaces of various materials. Its unquestionable advantage is the ability to collect spectra in situ conditions, especially useful in the analysis of reactions with the use of catalysts. The technique can be applied successfully in studies of zeolite catalysts. 
In this study, we confirmed the course of zeolite A spectra using the DRIFT technique. There were no clear differences in the FT-IR spectra of non-dehydrated selected samples (room temperature) exchanged with different ions. Measurements as a function of temperature allowed a new insight into the zeolite structure. Using DRIFT technique, observations could be made of dehydration and dehydroxylation processes of zeolites as well as some structural changes at higher temperatures.

The essential changes connected with the presence of non-tetrahedral cations could be observed in the expanded spectra in the $\mathrm{OH}$ stretching mode region. It was confirmed that, based on this spectral range, three types of water may be recognized in zeolite structure: typical zeolite water, water with crystal-water-like bonds, and water bound to the lattice by OH-bonds.

Supplementary Materials: The following are available online at https://www.mdpi.com/article/ 10.3390/ma14164642/s1, Figure S1: XRD patterns of various cationic form of zeolite A, Figure S2: FT-IR spectra of various cationic form of zeolite A, Figure S3: DRIFT spectra of zeolite Na-A recorded at $50{ }^{\circ} \mathrm{C}$ intervals (from 50 to $600^{\circ} \mathrm{C}$ ), Figure S4: DRIFT spectra of zeolite Ca-A recorded at $50{ }^{\circ} \mathrm{C}$ intervals (from 50 to $600{ }^{\circ} \mathrm{C}$ ), Figure S5: DRIFT spectra of zeolite $\mathrm{Cu}$-A recorded at $50{ }^{\circ} \mathrm{C}$ intervals (from 50 to $600{ }^{\circ} \mathrm{C}$ ), Figure S6: DRIFT spectra of zeolite Ni-A recorded at $50^{\circ} \mathrm{C}$ intervals (from 50 to $600^{\circ} \mathrm{C}$ ), Figure S7: DRIFT spectra of zeolite Zn-A recorded at $50^{\circ} \mathrm{C}$ intervals (from 50 to $600{ }^{\circ} \mathrm{C}$ ).

Author Contributions: Conceptualization, M.K.K.; methodology, M.K.K. and P.J.; software, M.K.K. and P.J.; validation, M.K.K. and P.J.; formal analysis, M.K.K.; investigation, M.K.K.; resources, M.K.K.; data curation, M.K.K. and P.J.; writing—original draft preparation, M.K.K.; writing—review and editing, M.K.K.; visualization, M.K.K.; supervision, M.K.K.; project administration, M.K.K.; funding acquisition, M.K.K. Both authors have read and agreed to the published version of the manuscript.

Funding: This work was financially supported by The National Science Centre Poland under grant no. 2016/21/D/ST8/01692.

Institutional Review Board Statement: Not applicable.

Informed Consent Statement: Not applicable.

Data Availability Statement: Data presented in this study are available on request from the corresponding author.

Conflicts of Interest: The authors declare no conflict of interest.

\section{References}

1. Breck, D.W. Zeolite Molecular Sieves, Chemistry and Use; John Wiley \& Sons: New York, NY, USA, 1974.

2. Baerlocher, C.; McCusker, L.B. Database of Zeolite Structures. Framework Type LTA (Material: Linde Type A, Zeolite A). 2020. Available online: http:/ / www.iza-structure.org/databases / (accessed on 19 July 2021).

3. Cejka, J.; van Bekkum, H. Zeolites and Ordered Mesoporous Materials: Progress and Prospects. Studies in Surface Science and Catalysis; Elsevier: Prague, Czech Republic, 2005.

4. Kühl, G.H. Preparation of Shape Selective Zeolite Alpha as Catalyst. U.S. Patent No. 4,191,663, 1979.

5. Reed, T.B.; Breck, D.W. Crystalline zeolites. II. Crystal structures of synthetic zeolite, type A. J. Am. Chem. Soc. 1956, 78, 5972-5977. [CrossRef]

6. Gramlich, V.; Meier, W.M. The crystal structure of hydrated NaA: A detailed refinement of a pseudosymmetric zeolite structure. Z. Kristallogr. 1971, 133, 134-149. [CrossRef]

7. Mortier, W.J. Compilation of Extra Framework Sites in Zeolites; Butterworth \& Co.: Leuven, Belgium, 1992.

8. Mikuła, A.; Król, M.; Koleżyński, A. Periodic model of an LTA framework. J. Mol. Model. 2015, 21, 275. [CrossRef]

9. Vanagida, R.Y.; Amaro, A.A.; Seff, K. A redetermination of the crystal structure of dehydrated zeolite 4A. J. Phys. Chem. 1973, 77, 805-809. [CrossRef]

10. Momma, K.; Izumi, F. VESTA 3 for three-dimensional visualization of crystal, volumetric and morphology data. J. Appl. Crystallogr. 2011, 44, 1272-1276. [CrossRef]

11. Peuker, C. In-Situ DRIFT measurements of OH vibrations in MFI-type zeolites. J. Mol. Struct. 1995, 349, 317-320. [CrossRef]

12. Beta, I.A.; Böhlig, H.; Hunger, B. Investigation of the non-isothermal water desorption on alkali-metal cation-exchanged X-type zeolites: A temperature-programmed diffuse reaction infrared Fourier transform spectroscopic (TP-DRIFTS) study. Thermochim. Acta 2000, 361, 61-68. [CrossRef]

13. Jentys, A.; Warecka, G.; Derewinski, M.; Lercher, J.A. Adsorption of water on ZSM 5 zeolites. J. Phys. Chem. 1989, 93, 4837-4843. [CrossRef] 
14. Ozorio, L.P.; Pianzolli, R.; da Cruz Machado, L.; Miranda, J.L.; Turci, C.C.; Guerra, A.C.O.; Falabella Souza-Aguiara, E.; Mota, C.J.A. Metal-impregnated zeolite $\mathrm{Y}$ as efficient catalyst for the direct carbonation of glycerol with $\mathrm{CO}_{2}$. Appl. Catal. A Gen. 2015, 504, 187-191. [CrossRef]

15. Conte, M.; Lopez-Sanchez, J.A.; He, Q.; Morgan, D.J.; Ryabenkova, Y.; Bartley, J.K.; Carley, A.F.; Taylor, S.H.; Kiely, C.J.; Khalid, K.; et al. Modified zeolite ZSM-5 for the methanol to aromatics reaction. Catal. Sci. Technol. 2012, 2, 105-112. [CrossRef]

16. Smith, L.H., Jr. Inorganic Synthesis; Wiley: New York, NY, USA, 1983; p. 33.

17. Kubelka, P.; Munk, F. Ein Beitrag Zur Optik Der Farbanstriche. Z. Tech. Phys. 1931, 12, 593-601.

18. Sun, H.; Wu, D.; Liu, K.; Guo, X.; Navrotsky, A. Energetics of alkali and alkaline earth ion-exchanged zeolite A. J. Phys. Chem. C 2016, 120, 15251-15256. [CrossRef]

19. Singh, J.; White, R.L. A variable temperature infrared spectroscopy study of CaA zeolite dehydration and carbonate formation. Spectrochim. Acta A 2019, 207, 189-196. [CrossRef] [PubMed]

20. Bish, D.L.; Carey, B. Thermal behavior of natural zeolites. Rev. Mineral. Geochem. 2001, 45, 403-452. [CrossRef]

21. Kosanovic, C.; Subotic, B.; Smit, I. Thermally induced phase transformations in cationexchanged zeolites $4 \mathrm{~A}, 13 \mathrm{X}$ and synthetic mordenite and their amorphous derivatives obtained by mechanochemical treatment. Thermochim. Acta 1998, 317, 25-37. [CrossRef]

22. Afzal, M.; Yasmeen, M.; Saleem, P.K.; Butt, A.K.; Afzal, J. TG and DTA study of the thermal dehydration of metal-exchanged zeolite-4A samples. J. Therm. Anal. Calorim. 2000, 62, 721-727. [CrossRef]

23. Mozgawa, W.; Jastrzębski, W.; Handke, M. Vibrational spectra of D4R and D6R structural units. J. Mol. Struct. 2005, 744-747, 663-670. [CrossRef]

24. Koleżyński, A.; Mikuła, A.; Król, M. Periodic model of LTA framework containing various non-tetrahedral cations. Spectrochim. Acta A 2016, 157, 17-25. [CrossRef]

25. Katoh, M.; Koide, R.; Yamada, K.; Yoshida, T.; Horikawa, T. IR spectroscopic analysis of thermal behavior of adsorbed water on Y-type zeolite. Int. J. Mod. Phys. Conf. Ser. 2012, 6, 437-442. [CrossRef]

26. Crupi, V.; Majolino, D.; Venuti, V. Diffusional and vibrational dynamics of water in NaA zeolites by neutron and fourier transform infrared spectroscopy. J. Phys. Condens. Matter. 2004, 16, S5297-S5316. [CrossRef]

27. Singh, J.; White, R.L. A variable temperature infrared spectroscopy study of NaA zeolite dehydration. Vib. Spectrosc. 2018, 94, 37-42. [CrossRef]

28. Gil, B.; Broclawik, E.; Datka, J.; Klinowski, J. Acidic hydroxyl groups in zeolites X and Y: A correlation between infrared and solid-state NMR spectra. J. Phys. Chem. 1994, 98, 930-933. [CrossRef]

29. Jiang, M.; Karge, H.G. Investigation of acid properties of dealuminated H-mordenite zeolites by low-temperature diffuse reflectance FTIR. J. Chem. Soc. Faraday Trans. 1996, 92, 2641-2649. [CrossRef]

30. Montanari, T.; Busca, G. On the mechanism of adsorption and separation of $\mathrm{CO}_{2}$ on LTA zeolites: An IR investigation. Vib. Spectrosc. 2008, 46, 45-51. [CrossRef]

31. Jobic, H. Observation of the fundamental bending vibrations of hydroxyl groups in $\mathrm{HNa}-\mathrm{Y}$ zeolite by neutron inelastic scattering. J. Catal. 1991, 131, 289-293. [CrossRef]

32. Beck, K.; Pfeifer, H.; Staudte, B. Assignment of novel bands observed in the near infrared spectra of shallow-bed treated H-Y and H-ZSM-5 zeolites. Micropor. Mater. 1993, 2, 1-6. [CrossRef]

33. Abd El Maksod, I.H.; Saleh, T.S.; Hegazy, E.Z. Preparation, characterization and utilization of (Ni:Cu) bimetallic system loaded on zeolites. J. Alloys Compd. 2010, 506, 923-927. [CrossRef]

34. Ohnishi, N.; Horikawa, Y.; Kajitani, T.; Morii, Y.; Hiraga, K. Neutron powder diffraction study of Ni-LTA zeolite. Phys. B Condens. Matter 1995, 213-214, 408-410. [CrossRef]

35. Esquivel, D.; Cruz-Cabeza, A.J.; Jiménez-Sanchidrián, C.; Romero-Salguero, F.J. Transition metal exchanged $\beta$ zeolites: Characterization of the metal state and catalytic application in the methanol conversion to hydrocarbons. Microporous Mesoporous Mater. 2013, 179, 30-39. [CrossRef]

36. Nyankson, E.; Efavi, J.K.; Yaya, A.; Manu, G.; Asare, K.; Daafuor, J.; Abrokwah, R.Y. Synthesis and characterisation of zeolite-A and Zn-exchanged zeolite-A based on natural aluminosilicates and their potential applications. Cogent. Eng. 2018, 5, 1440480. [CrossRef]

37. Majdan, M.; Pikus, S.; Kowalska-Ternes, M.; Gładysz-Płaska, A.; Staszczuk, P.; Fuks, L.; Skrzypek, H. Equilibrium study of selected divalent d-electron metals adsorption on A-type zeolite. J. Colloid Interface Sci. 2003, 262, 321-330. [CrossRef]

38. Baker, M.D.; Godber, J.; Helwig, K.; Ozin, G.A. Probing extra-framework cations in alkali- and alkaline-earth-metal linde type A zeolites by Fourier Transform Far-Infrared Spectroscopy. J. Phys. Chem. 1988, 92, 6017-6024. [CrossRef]

39. Blackwell, C.S. Investigation of zeolite frameworks by vibrational properties. 1. The double-four-ring in group 3 zeolites. J. Phys. Chem. 1979, 83, 3251-3257. [CrossRef]

40. Takaishi, T.; Yatsurugi, Y.; Yusa, A.; Kuratomi, T. Changes in the sieving action and thermal stability of zeolite a produced by ion-exchange. J. Chem. Soc. Faraday Trans. 1976, 71, 97-105. [CrossRef]

41. Radulović, A.; Dondur, V.; Dimitrijević, R.; Arandjelović, D. Thermal transformation of Na-LTA zeolite into low-carnegieite: The influence of residual sodium and aluminium species. Thermochim. Acta 2010, 511, 37-42. [CrossRef] 